\title{
Pengaruh Karakteristik Pekerjaan, Pengembangan Karir Dan Kompensasi Terhadap Loyalitas karyawan
}

\author{
Charlos Alexander Lumiu \\ Riane Johnly Pio \\ Ventje Tatimu \\ Program Studi Administrasi Bisnis, Jurusan Ilmu Administrasi, \\ Fakultas Ilmu Sosial dan Politik, Universitas Sam Ratulangi \\ Email: charleslumiu@gmail.com
}

\begin{abstract}
This study aims to examine the effect of job characteristics, career development and compensation on employee loyalty. The potential of existing human resources in the company must be utilized as well as possible, so as to be able to provide optimal output. An organization will run smoothly if all services provided by individuals to the organization get balanced attention and rewards. The general research objective is to examine and determine the effect of job characteristics, career development and compensation on employee loyalty. The method used in this research is quantitative descriptive method, using Structural Equation Modeling with Partial Least Square. The results obtained from the study that simultaneously the ability of the variable Job Characteristics, Career Development and Compensation in explaining the magnitude of the influence on the variable Employee Loyalty is $14 \%$, the rest is explained by other variables outside this study.
\end{abstract}

Keywords: Job Characteristics, Career Development, Compensation and Employee Loyalty

\section{Latar Belakang}

Pada era globalisasi saat ini, manusia memiliki kedudukan yang penting. Salah satu sumber daya yang terdapat dalam perusahaan adalah sumber daya manusia. Sumber daya ini dirasakan semakin penting karena pengendali dan pengelola perusahaan adalah manusia.

Tanpa faktor manusia seluruh sumber daya perusahaan tidak dapat dimanfaatkan dan dikelola dengan baik. Potensi sumber daya manusia yang ada dalam perusahaan harus dapat dimanfaatkan dengan sebaikbaiknya, sehingga mampu memberikan output secara optimal. Suatu organisasi akan berjalan lancar bila semua jasa yang disumbangkan para individu kepada organisasi mendapat perhatian dan imbalan yang seimbang.

Potensi sumber daya manusia yang ada dalam perusahaan harus dapat dimanfaatkan dengan sebaik-baiknya, sehingga mampu memberikan output secara optimal. Suatu organisasi akan berjalan lancar bila semua jasa yang disumbangkan para individu kepada organisasi mendapat perhatian dan imbalan yang seimbang. 
PT. Aura Cantik Indonesia merupakan perusahaan swasta yang bergerak di industri kecantikan yang berkantor di Hotel Prince Boulevard. Adapun masalah-masalah yang menyangkut karakteristik pekerjaan, pengembangan karir, kompensasi dan loyalitas karyawan yang ada saat ini pada PT. Aura Cantik Indonesia Cabang Manado Karakteristik pekerjaan mengacu pada isi dan kondisi dari tugas-tugas pekerjaan itu sendiri. Menurut teori karakteristik pekerjaan, sebuah pekerjaan memiliki tiga keadaan psikologis dalam diri seorang karyawan yakni: (1) meglami makna kerja (2) memikul tanggung jawab akan hasil kerja (3) dan pengetahuan akan hasil kerja, dan ketiga kondisi psikologis ini akan mempengaruhi motivasi kerja, kinerja, perputaran karyawan, serta loyalitas kerja karyawan.

Setiap karyawan harus diberi kesempatan untuk mengembangkan karirnya, yakni sebagai alat untuk menjaga loyalitas setiap karyawan. Pengembangan karir juga dapat menumbuhkan komitmen bagi karyawan.

Kompensasi adalah segala sesuatu yang diterima dapat berupa fisik maupun non fisik dan harus dihitung dan diberikan kepada seseorang yang umumnya merupakan objek yang dikecualikan dari pendapatan. Pengelolaan kompensasi merupakan kegiatan yang sangat penting dalam memberikan kepuasan bagi karyawan dalam pekerjaannya. Loyalitas karyawan merupakan salah satu faktor yang mempengaruhi keberadaan perusahaan. Loyalitas karyawan tidak hanya diukur dari kesetiaannya terhadap perusahaan, yang lebih penting karyawan dapat memberikan kontribusi berarti bagi perusahaan. Tingkat loyalitas karyawan akan sangat mempengaruhi kinerja karyawan dan produktivitas sebuah perusahaan. Perusahaan tidak bisa berjalan dengan baik bila pengelolaan karyawan akan pekerjaannya tidak dikelola dengan baik.

Dari uraian tersebut maka penulis tertarik mengangkat judul penelitian tentang "Pengaruh Karakteristik Pekerjaan, Pengembagan Karir dan Kompensasi Terhadap Loyalitas Karyawan pada PT. Aura Cantik Indonesia Cabang Manado.

\section{Karakteristik Pekerjaan}

Luthan (2013), karakteristik pekerjaan merupakan bagian dari desain tugas yang berupa ruang lingkup kerja yang memiliki dimensi macam-macam kemampuan, identitas tugas, signifikansi tugas, otonomi dan umpan balik.

Kelima dimensi karakteristik perkerjaan tersebut menciptakan tingkat reaksi psikologis seseorang tentang makna, tanggung jawab, serta pengetahuan yang 
dihasilkan dari pekerjaan tersebut pada akhirnya berdampak pada motivasi, kinerja, dan kepuasan kerja karyawan serta tingkat kemungkinan dan tingkat keluar masuknya karyawan.

\section{Teori Karakteristik Pekerjaan}

Teori Karakteristik Pekerjaan merupakan suatu model kontemporer yang penting tentang bagaimana mendesain pekerjaan, dengan menggunakan lima karakteristik pekerjaan inti, para manajer dapat meningkatkan tiga keadaan psikologis kritis, keadaan ini nantinya dapat meningkatkan variasi personal dan hasil kerja. Perbedaan individual juga mempengaruhi bagaimana karakteristik pekerjaan mempengaruhi orang-orang (Griffin 2013)

\section{Pengembangan Karir}

Pengembangan karir sangat penting bagi suatu organisasi, karena karir merupakan kebutuhan yang harus terus dikembangkan dalam diri seorang pegawai sehingga mampu memotivasi karyawan untuk meningkatkan kinerjanya.

$$
\text { Robins (2016) mengatakan }
$$

pengembangan karir merupakan suatu cara bagi sebuah organisasi untuk mendukung atau meningkatkan produktivitas para karyawan dewasa ini, sementara sekaligus mempersiapkan mereka untuk dunia yang berubah.

\section{Faktor-faktor Pengembangan Karir}

Faktor-faktor pengembangan karir menurut wahyono (2015), antara lain: (1) Kinerja, (2) Exposure, (3) Leveraging, (4) Dedikasi, (5) Mentor dan Sponsor, (6) Edukasi.

\section{Kompensasi}

Gary Dessler (2016) mengatakan bahwa kompensasi adalah segala bentuk pembayaran atau imbalan yang diberikan kepada karyawan dan timbul dari hubungan kerja mereka.

\section{Tujuan Kompensasi}

Kompensasi yang diberikan perusahaan berbeda-beda antara karyawan satu dengan yang lainnya. Kompensasi juga sangat sensitif bagi manajemen perusahaan dalam pelaksanaannya. Dengan adanya tujuan kompensasi yang jelas maka perusahaan perlu serius dalam memberikan kompensasi kepada karyawan.

Tujuan dari diberikannya kompensasi antara lain (Hasibuan 2013:121): (1) Ikatan kerja sama, (2) Kepuasan kerja, (3) Pengadaan efektif, (4) Motovasi, (5)Stabilitas karyawan, (6) Disiplin (7) Pengaruh serikat buruh 


\section{Komponen-komponen Kompensasi}

Komponen-komponen kompensasi antara lain (Rivai dan Jauvani 2011):
1. Gaji
2. Upah
3. Insentif
4. Kompensasi tidak langsung

\section{Loyalitas Karyawan}

Loayalitas merupakan sikap kesetiaan yang ditunjukan oleh seseorang melalui pelayanan maupun tanggung jawab dengan perilaku terbaik. Dalam melaksanakan kegiatan kerja, karyawan tidak akan terlepas dari loyalitas dan sikap kerja, sehingga dengan demikan karyawan tersebut akan selalu melaksanakan pekerjaan dengan baik. Menurut Reichheld dalam tulisan Sidik (2016:8) semakin tinggi loyalitas karyawan di suatu organisasi, maka semakin mudah organisasi itu untuk mencapai tujuan-tujuan organisasi tersebut yang telah ditetapkan sebelumnya oleh pemilik organisasi.

\section{Faktor-faktor Yang Mempengaruhi Loyalitas Karyawan}

Karyawan yang merasa puas memiliki loyalitas yang sangat tinggi terhadap organisasi. Rendahnya kepuasan kerja ini mendorong karyawan untuk tidak komit terhadap organisasi, sehingga merugikan organisasi itu sendiri seperti menurunnya prestasi kerja, rendahnya semangat kerja, menurunnya tingkat disiplin.

Faktor-faktor pembentuk loyalitas orgasisasional akan berbeda bagi karyawan yang baru bekerja, setelah menjalani masa kerja yang cukup lama, serta bagi karyawan yang bekerja dalam tahapan yang lama menganggap perusahaan atau organisasi tersebut sudah menjadi bagian dalam hidupnya.

Yuliandri dalam dalam Triyono (2012:45) menegaskan bahwa faktor-faktor yang mempengaruhi loyalitas karyawan adalah: (1) Adanya fasilitas-fasilitas kerja, (2) Tunjangan kesehatan, (3) Suasana kerja, (4) Upah yang diterima dari perusahaan.

\section{Jenis Penelitian}

Metode yang digunakan adalah deskriptif kuantitatif dengan menggunakan Pemodelan Persamaan Struktural dengan Partial Least Squre.

\section{Populasi dan Sampel Penelitian}

Populasi penelitian adalah karyawan pada PT. Aura Cantik Indonesia Cabang Manado. Metode pengambilan sampel dengan menggunakan teknik NonProbability Sampling, sampel yang diambil adalah seluruh karyawan pada PT. Aura Cantik Indonesia yang berjumlah 40 orang. 


\section{Metode pengumpulan data}

\section{Data Primer}

Data primer adalah sumber data yang langsung memberikan data kepada pengumpulan data. Sugiyono (2013)

Kuesioner (Angket)

Kuesioner yaitu metode pengumpulan data dengan cara memberikan sejumlah pertanyaan tertulis kepada responden atau para karyawan untuk mendapatkan informasi yang diperlukan

\section{Data Sekunder}

Data sekunder merupakan sumber data yang tidak langsung memberikan data, misalnya seperti lewat orang lain ataupun lewat dokumen. Sugiyono (2013). Dalam hal ini yang menjadi objek penelitian adalah data karyawan yang telah diolah dari PT. Aura Cantik Indonesia seperti sejarah, visi, misi, dan struktur organisasi.

\section{Teknik Analisa Data}

Pemodelan persamaan struktural yang sering disebut dengan Structural Equation Modeling (SEM) adalah Teknik analisis multivariat yang umum dan sangat bermanfaat yang meliputi versi-versi khusus dalam jumlah metode analisis lainnya sebagai kasus-kasus khusus.

Teknik analisis data menggunakan Structural Equation Modeling (SEM), dilakukan untuk menjelaskan secara menyeluruh hubungan antar variabel yang ada dalam penelitian, syarat utama menggunakan SEM adalah membangun suatu model hipotesis yang terdiri dari model struktural dan model pengukuran dalam bentuk diagram jalur yang berdasarkan justifikasi teori.

\section{Evaluasi Model Pengukuran (Outer Model)}

Outer model menentukan spesifikasi hubungan antara konstruk laten dengan indikatornya. Evaluasi ini juga disebut evaluasi terhadap konstruk/variabel laten. Terdapat dua macam jenis konstruk yaitu konstruk reflektif dan konstruk formatif. Konstruk reflektif membutuhkan pengujian validitas dan reliabilitas konstruk, sedangkan konstruk formatif pengukuran dilakukuan hanya dengan melihat signifikansi weight-nya saja, penelitian ini menggunakan konstruk reflektif.

\section{Evaluasi Model Struktural (Inner Model) Langkah selanjutnya setelah melakukan evaluasi model pengukuran (outer model) adalah melakukan evaluasi struktural (inner model). Inner model menentukan spesifikasi hubungan antara konstruk laten dengan konstruk laten lainnya.}




\section{Pembahasan}

Berdasarkan hasil pengujian hipotesis, ditemukan bahwa variabel Karakteristik Pekerjaan berpengaruh signifikan dan negatif terhadap Loyalitas Karyawan. Artinya semakin tinggi Karakteristik Pekerjaan akan mengakibatkan semakin rendah Loyalitas Karyawan. Manajer perusahaan harus lebih memotivasi para karyawan agar memiliki motivasi kerja yang tinggi sehingga memiliki kepuasan kerja yang tinggi yang juga diharapkan dapat lebih meningkatkan loyalitas karyawan

Berdasarkan hasil pengujian hipotesis, ditemukan bahwa variabel Pengembangan Karir tidak berpengaruh signifikan dan positif terhadap Loyalitas Karyawan. Artinya semakin tinggi Pengembangan Karir tidak akan mengakibatkan tinggi rendahnya Loyalitas Karyawan. Tujuan pengembangan karir pada perusahaan belum dirasakan oleh para karyawan.

Berdasarkan hasil pengujian hipotesis, ditemukan bahwa variabel Kompensasi memiliki hubungan secara langsung dengan variabel loyalitas karyawan. Artinya semakin tinggi kompensasi akan mengakibatkan semakin tinggi loyalitas karyawan.

Hasil Penelitian ini juga sesuai dengan hasil penelitian terdahulu yang dilakukan oleh yati suhartini (2017) dengan judul Analisis Faktor-faktor Yang Mempengaruhi Loyalitas Karyawan Pada Pertokoan di Sepanjang Jalan Malioboro Yogyakarta bahwa penyempurnaan sistem kompensasi yang baik dan tercipta keadilan secara eksternal akan memperbaiki dan meningkatkan loyalitas karyawan. Sehingga antara kompensasi dan loyalitas karyawan terdapat hubungan yang positif, artinya apa-bila kompensasi ditingkatkan maka loyalitas karyawan juga akan meningkat.

Berdasarkan hasil pengujian hipotesis, ditemukan bahwa variabel variabel Karakteristik Pekerjaan, Pengembangan Karir dan Kompensasi secara simultan mempengaruhi variabel Loyalitas Karyawan.

Hasil Penelitian ini juga sesuai dengan hasil penelitian terdahulu yang dilakukan oleh Anjelika Wulan Tamba (2018) dengan judul Pengaruh Disiplin Kerja Dan Loyalitas Karyawan Terhadap Kinerja Karyawan Pada PT. Columbindo Perdana Cabang Manado bahwa perusahaan perlu mereview kembali mengenai Loyalitas karyawan sehingga kedepannya, sehingga boleh memberikan dampak yang positif bagi jalannya bisnis perusahaan. 


\section{Simpulan}

Dengan mempertimbangkan realita ketatnya kompetisi dalam bisnis serta memperhatikan bukti empiris dari hasil penelitian ini, maka pengusaha dan manajemen sebaiknya memberikan perhatian pada karakteristik pekerjaan, pengembangan karir dan kompensasi sehingga loyalitas karyawan dapat terjaga.

Perbaikan loyalitas karyawan mengarah kepada tingkat kesetiaan karyawan dalam melaksanakan tugas yang telah dibebankan kepadanya. Karena loyalitas yang tinggi, karyawan akan bekerja dengan segenap kemampuan dan skill yang dimilikinya untuk bisa menghasilkan kinerja dan produktivitas yang memuaskan.

Para karyawan juga kiranya bisa lebih menghargai bahkan mencintai pekerjaan yang digeluti saat ini dan jika terdapat kekurangan dalam proses operasional kiranya boleh langsung dikoordinasikan dengan atasan sehingga dapat diambil jalan keluar dan tidak menimbulkan masalah kedepannya.

\section{Referensi}

Dessler, G. 2016. Manajemen Sumber Daya Manusia, edisi 14. Jakarta: Salemba Empat.

Griffin, M. 2013. Perilaku Organisasi Manajemen Sumber Daya Manusia dan Organisasi. Jakarta: Salemba Empat.

Hasibuan, S.P.M. 2013. Manajemen Sumber Daya Manusia. Cetakan ketujuh belas. Jakarta: Bumi Aksara.

Rivai, V dan Sagala, E.J. 2011. Manajemen Sumber Daya Manusia Untuk Perusahaan. Jakarta: Raja Grafindo Persada.

Robbins, S.P. 2016. Perilaku Organisasi. Jilid 2, edisi Bahasa Indonesia. Jakarta: PT. Prehallindo.

Sidik, R. 2016. Pengaruh Loyalitas Dan Motivasi Terhadap Produktivitas Karyawan Pada Wahid Galeri Seni Ukir. Universitas Bina Darma.

Sugiyono. 2013. Metode Penelitian dan Bisnis. Bandung: Alfabeta

Suhartini, Y. 2017. Analisis Faktor-faktor Yang Mempengaruhi Loyalitas Karyawan Pada Pertokoan di Sepanjang Jalan Malioboro Yogyakarta. Jurnal Akuntansi dan Manajemen Vol.14 No.2 Tahun 2017

Tamba, A.W., Pio, R.J., dan Sambul, S. 2018. Pengaruh Disiplin Kerja Dan Loyalitas Karyawan Terhadap Kinerja Karyawan Pada PT. Columbindo Perdana Cabang Manado. Jurnal Administrasi Bisnis Vol.7 No.1 Tahun 2018. 
Jurnal Administrasi Bisnis (JAB)

Vol. 9. No. 3, 2019

(p-ISSN 2338-9605; e-2655-206X)

Triyono, 2012. Faktor-Faktor Penentu

Yang Memepengaruhi Loyalitas

Karyawan. Skripsi Universitas

Muhammadiyah Surakarta.

Luthan, F. 2013. Perilaku Organisasi Edisi

10. Yogyakarta: ANDI.

Wahyono, S.I. 2015. Manajemen Sumber

Daya Manusia. Jakarta: Salemba

Empat 